\title{
Arijana Luburić-Cvijanović
}

University of Novi Sad

Faculty of Philosophy

Novi Sad, Serbia

\section{Viktorija Krombhole ${ }^{* *}$}

University of Novi Sad

Faculty of Philosophy

Novi Sad, Serbia

\section{WILL SELF'S “GARDEN OF UNEARTHLY DELIGHTS": THE ANTIHERO AND THE CITY IN DORIAN: AN IMITATION}

\begin{abstract}
Will Self's Dorian: An Imitation recasts the decadence and wit of Oscar Wilde's narrative as the full-blown excess of image-obsessed contemporary Britain riddled with drugs, AIDS, and terminal boredom. Brutal satire and imagery of death, war, disease, and destruction align the novel with the contemporary genre of transgressive fiction which has established a new satiric tradition. The aim of this article is to analyse Self's novel within that tradition by examining the antihero as the epitome of his age and the city as the transgressive locus terribilis.
\end{abstract}

Key words: antihero, city, Dorian: An Imitation, satire, transgressive fiction, Will Self

E-mail address: alcvijanovic@ff.uns.ac.rs

*** E-mail address: viktorija.krombholc@ff.uns.ac.rs 


\section{Introduction}

As one of the most daring and controversial genres of contemporary literature, transgressive fiction has attracted quite a lot of readerly and media attention. Its appeal is such that Robin Mookerjee goes so far as to consider it the most significant literary movement of our time. Even if Mookerjee's claim is somewhat exaggerated and unconvincing, transgressive fiction is beyond doubt a prolific and radical genre that draws on a centuries-long satiric tradition to deliver its social critique. First coined in 1993, the term "transgressive fiction" has come to refer to a wide variety of authors, from Bret Easton Ellis and Chuck Palahniuk to Angela Carter and Martin Amis, who are said to belong to a new satiric tradition. Frequently criticised for its matter-of-fact representation of taboo content and misjudged as a call for violence, transgressive fiction as a form of satire has not received enough serious scholarly attention, so this article is an attempt to add to the existing debates. By first outlining transgressive fiction as a mode and genre and then focusing on Will Self's Dorian: An Imitation (2002), we wish to show how the transgressive energies of the novel are mobilized to satirize the (self-)destructive tendencies, institutions, ideologies, and moral relativism of the 1980s and 1990s in Britain.

While the lyricism of Self's prose aligns Dorian: An Imitation with modernism, its unforgiving satire and brave portrayal of unpleasant subjects define the novel as a transgressive postmodern satire. As the title suggests, Dorian: An Imitation is a rewriting of Oscar Wilde's provocative novel on the pursuit of eternal youth. Recasting aestheticism and gay subculture at the turns of two centuries - the 1890s in Wilde's original and the 1980s and 1990s in Self's "imitation" - Self's novel focuses on the hedonism and decadence of the wealthy few but paints a disturbing broader picture of British society consumed by excess, social and political crises, and the AIDS epidemic. Wilde's characters are recast as Henry Wotton, an outed homosexual and drug addict, Baz Hallward, a video artist whose installation Cathode Narcissus redefines Wilde's painting for a narcissistic age, and the sexually omnivorous epitome of the time's narcissism, Dorian. Together with a group of so-called friends, lovers, and acquaintances, they expose the agenda of the entrepreneurial 80s as essentially selfish as the story delves into the life of the stigmatized gay community against the background of an image-obsessed world marked by perpetual conflict and a near-total lack of empathy. 
Despite the obvious transgressive features, Dorian: An Imitation has mostly been read within other theoretical frameworks, such as NeoVictorianism, so this article wishes to offer a new perspective on Self's novel. The aim is to read it within the tradition of satiric transgressive fiction and specifically examine the role of its most characteristically transgressive aspects, the antihero and the city, in Self's critique. To do so, the article employs Robin Mookerjee's and M. Keith Booker's theoretical considerations of the development, features, and varieties of transgressive fiction both as a mode and as a genre. To properly understand the links that the novel establishes between transgression, the body, sexuality, and death, the analysis also relies on Michel Foucault's theorization of transgression, Georges Bataille's reflections on desire, eroticism, and death, as well as Julia Kristeva's insights into narcissism and the abject. Finally, in its exploration of the threatening and disordered city as the staple setting of both urban dystopia and transgressive fiction, the article enters into a dialogue with some of the latest theoretical literature on the city in contemporary fiction. For the purpose of providing a wider context for the interpretation of Self's novel, the article starts by tracing a brief history of transgressive fiction.

\section{Transgressive fiction: mode and/or genre?}

Drawing clear theoretical demarcation lines is at times notoriously difficult, so it comes as no surprise that transgressive fiction can and should be understood as both mode and genre, where transgression possibly implies the traversing of any boundaries, formal, generic, linguistic, or cultural, and not only those of conventional morality. To hint at the usefulness of such a broad view of transgressive literature in general, one needs only to think of the complexity of transgression in magical realism, itself read as both mode and genre, transgressive in its defining criss-crossing of the boundary between fantasy and reality, and inclusive of particularly subversive transgressive variants intent on disruption of fixed categories (Bowers 2004: 66-82). Unlike magical realism, however, transgressive fiction as a genre reflects transgression primarily as "profanation in a world which no longer recognizes any positive meaning in the sacred" (Foucault 1977: 30), as such present, though by no means inevitable, in transgressive literature and mythology since antiquity. 
From its birth as a mode in the works of forerunners like Ovid, a "proto-transgressive author" (Mookerjee 2013: 33), to its contemporary transformation into a genre, transgressive literature has been characterized by violence, moral ambiguity, sexual deviancy, transformation, and satirical views of society, its norms and systems of belief. In its modern varieties, transgressive fiction expectedly also disturbs the form of the traditional novel, redefines generic categories, and reaches far beyond the standards of propriety in language. All these features are now seen to have determined transgressive fiction as a distinct genre emerging in the 1970s, with a few earlier novels, notably Lolita (1955) and Naked Lunch (1959), which are read as transgressive in the contemporary sense. In the course of a few decades, the genre has become so prolific and attention-drawing that Robin Mookerjee considers it "the most significant literary movement of our time" (Mookerjee 2013: 14). While Mookerjee perhaps places too much importance on a single genre, transgressive fiction does attract a wide readership by its controversial content and manner of representation which boost publicity and sales, and is undoubtedly among the most provocative genres today.

Together with similarly cult recent genres like bizarro fiction, transgressive fiction evolved from the 1970s' interest in the grotesque in writers like Martin Amis, Ian McEwan, Phillip Roth, J. G. Ballard, or Kathy Acker, whose works offer savagely bitter, satirical, and disturbing portraits of corrupted contemporary society reigned by death, sexual and psychological perversion, drugs, alcohol, violence, and madness, frequently conjoined with a willingness to shock and narrative selfconsciousness. These "troubled moralists ... of an increasingly grotesque and alien world" or "troubling, self-conscious, experimental visionaries" (Bradbury 1993: 390-91) depict social and psychological disorder, and the resultant breakdown of the self, in a fantasy- or thrillerlike world whose moral constitution is set in doubt. Having reached its peak in the 1980s and 90s, transgressive fiction was first marked out as a genre and termed transgressive in a 1993 article by Michael Silverblatt, who defined American transgressive writing as having "violation at its core: violation of norms, of humanistic enterprise, of the body" (Silverblatt 1993). This determinative trait has inspired other terms whose derogatory ring defies their initially descriptive purpose. Kathryn Hume's aggressive fiction and James Annesley's blank fiction refer equally to content, style, and an author's disposition, but neither encompasses all transgressive fiction, nor does it always seem to grasp its implications. 
Mookerjee attempts to compensate for this failure by outlining transgressive fiction as a subgenre of postmodernism consistent with the satiric tradition, at the same time acknowledging that the rhetoric of transgression is also closely related to modernism (Mookerjee 2013: 6; 9). He traces its origins to the earliest satirists, Petronius, the Menippean school, and Ovid, who dealt with one dominant, "overarching mythology", while contemporary satirists share their predecessors' obscure, ambiguous, and evasive authorial presence but face a number of systems and beliefs (Mookerjee 2013: 2-3). Through satire, transgressive fiction is linked with folk literature, itself a response to the norm, and follows up on major satirists like Jonathan Swift, George Gordon Byron, and Marquis de Sade. Although contemporary transgressive fiction often draws inspiration from the satiric tradition, in his analysis of Salman Rushdie, M. Keith Booker points out that the satiric edge is common but not indispensable in transgressive works (Booker 1991: 49-71). It is, however, vital to Will Self's writing, which would belong to what Mookerjee calls "the transgressive canon" (Mookerjee 2013: 147) if the notion of the canon were not so questionable.

Satiric or not, contemporary transgressive fiction is a topic of endless heated debates and an (un)intentional target of harsh criticism. Despite its involvement in the dismantling of institutions and ideologies, the genre is continuously berated in literary criticism precisely for its matter-of-fact representation of "unpleasant content" (Mookerjee 2013: 1). Kathryn Hume's impressionistic reading of American fiction since the 1970s as "designed not to give readers pleasure" (Hume 2012: ix) serves well to illustrate this tendency. In a text prone to gross generalizations, Hume asserts that these "aggressively off-putting novels" inevitably make the readers feel "attacked and abused", and widely uses terms such as "user-unfriendly fiction", "aggressive fictions", "irritating fictions", or "transgressive fiction" (Hume 2012: ix-X; 40; 25) to cover novels as diverse as Phillip Roth's Portnoy's Complaint (1969), Bret Easton Ellis's American Psycho (1991), and Cormac McCarthy's The Road (2006). The sheer frequency of such views shows that transgressive fiction is certainly and purposefully unpleasant. While undermining literary paradigms and beliefs, transgressive fiction upsets by its straightforward representation of taboo subjects like extreme violence, bizarre behaviour, deviant and pornographic sexuality, abuse of drugs, or disease. All conventional notions concerning family, human relations, the body, or morality are thrown in disarray in critical considerations of sexuality and society, the two major themes of transgressive fiction 
according to Mookerjee (Mookerjee 2013: 5). Its dystopian cities abound in imagery of destruction, decay, grotesquerie, and monstrosity, with the city and body as mirror images of each other.

Central to these fictions' transgressive standpoint is the figure of the alienated, antisocial, immoral/amoral, at times monstrous and brutally honest antihero. Endowing him with doubles - Patrick Bateman/Paul Owen in American Psycho, Joe/Tyler in Fight Club (1996), John Self/ Fielding Goodney in Money (1984), Dorian/Narcissus in Dorian: An Imitation - allows authors to blur the distinction between right and wrong, good and evil, normal and deviant. Most disturbing of all is transgressive fiction's blunt, morally neutral or ambiguous manner of presentation which collapses the distance between reader and content (Mookerjee 2013: 2 ), enabling authors, whose implied presence is seen as inherited from the earliest satirists, to refrain from any moral stand. The genre, which exhibits a clear preference for the confessional mode, is therefore seen as more "interrogative than declarative" (Mookerjee 2013: 174) and critical of specific cultures and their value systems or the contemporary world at large, making "a socially relevant statement" (Mookerjee 2013: 1).

Transgressive fiction has proven time and again that it certainly can be a vehicle for political statements as the "transgressive energies of literature $\ldots$ are directed ... at dominant institutions and ideologies in the real world of politics and history" (Booker 1991: 3). Its social critique is often expressed in the "flat, clinical" (Mookerjee 2013: 1) style of which Ellis is taken as exemplary. Silverblatt's claim that American transgressive authors "take the simple declarative sentences of the minimalists a few notches further toward blankness or numbness" (Silverblatt 1993) has inspired Mookerjee to postulate the existence of the transgressive style. While it is characteristic of a number of authors like Ellis or Palahniuk, others like Nabokov, Amis, Self, or Angela Carter show that there is no such thing as the transgressive style. Yet, in all its varieties, style seems to provide a significant contrast to the subject matter. Blank style helps present morally suspect content in a neutral way, turning into an instrument of mockery when, for example, the language of advertising in American Psycho parodies an obsession with brands and status symbols among yuppies in the 1980s. On the other hand, the stylistic and verbal mastery of a Nabokov, Carter, Amis, or Self can act as a screen that "obscures ... violent acts" (Mookerjee 2013: 94) or beautifies them. 
All these features are carefully juggled in transgressive fiction to express an antipathy to systems, to mock and/or defy "proscriptive tendencies that attend broad belief systems", using the specialized language of commerce, technology, or advertising for parodic purposes (Mookerjee 2013: 3-5). Transgressive fiction voices an "uncompromising aversion to all formulae that organize experience" (Mookerjee 2013: 8) in a spirit of carnivalesque anarchy which makes ample use of inversion, duality, doubles, the profane, carnality, sexuality, the grotesque, transgression of boundaries, ex-centricity, mockery of the official/normative, and degradation of the revered. In tune with Bataille's assertion that "[o]ften the transgression is permitted, often it is even prescribed" (Bataille 1986: 63), Booker reminds us that the carnival is authorized transgression (Booker 1991: 6), giving rise to one of the numerous ambiguities of the genre, which newer generations of transgressive authors seem to abandon in favour of more explicitly disturbing material (Mookerjee 2013: 100). Both ambiguity and disturbance play an important part in the harsh portrayals of values and culture in Self's Dorian: An Imitation, a novel which defies the idea of a blank, flat style as symptomatic of transgressive fiction. Self's transgressive rewriting of Wilde's equally transgressive original employs various aspects of transgression to satirically examine contemporary British society, and its critique is most persuasively delivered through the antihero and the city.

\section{The transgressive antihero as the epitome of an era}

Like the tellingly named John Self in Money, virtually all protagonists of Will Self's metafictional revision of Wilde's The Picture of Dorian Gray (1891) pose as antiheroic epitomes of their eras, the 1980s and 1990s. The 1980s are suggestively called "Dorian's decade" (Self 2003: 108), a decade marked in Self's novel as one in which the antihero seeks closeness with death through drug and alcohol abuse, unprotected sex, and murder. As M. Hunter Hayes observes, "[r]ather than a will to live, the characters in Dorian embody a nihilistic compulsion" (Hayes 2007: 148). Most in their late twenties or early thirties, Dorian, Wotton, and the rest of Self's set engage in abusive treatment of others and self-destructive behaviour which, ten years later, leaves their battered bodies in ruins. The systematic and gradual (self-)destruction mirrors the entrepreneurial 80s with their discourse founded on myths of money of the socially and culturally 
privileged, the self-employed, consumerism, and junk culture. Although the time's anti-immigration politics and race riots remain confined to the background, Self's focus on mostly upper-class gay subculture decadence, marked by moral corruption, drugs, eccentricities of all kinds, terminal boredom, and self-destructive tendencies, may be read as a response to the decade's partiality to traditional family values that effectively outlawed positive gay and lesbian images. The 1990s are no less reflected by the novel's prevailing sense of class divisions which also reverberate in the background as Self eschews explicit treatment of the 1990s' underclass cut off from consumer society, or the growth of poverty and homelessness which sparked off riots in poor urban areas. Instead, an image of a divided Britain and a divided world, marked by a loss of all innocence and hope, serves as the framework for ruminations on the decadence of a social microcosm which, as the author reveals in an interview with Laurie Taylor, refrain from moral judgment to make the readers think for themselves in a time of moral relativism (Taylor 2007).

Moral relativism is most convincingly articulated in the novel by vampire-like Wotton, a prototype of upper-class snobbery and affectation signalled by his compulsive use of French, and the voice of disillusionment whose bitterly ironic commentary on the world speaks of contempt for humanity which earns him the comparison with "poison running in the gutter" (Self 2003: 23). It is Dorian himself, however, who best illustrates the moral and physical decay of the image-obsessed decades in an intricate play between representation and reality. As in Wilde's novel, Dorian's physical degradation as a reflection of his ever-deeper immersion in immorality is hidden from view and it is the appearance that becomes the reality. Self's Dorian is an embodiment of Baudrillard's simulacrum who finds "acting so much more real than reality", "in an age when appearances matter more and more", and even flower arrangements seem "anti-natural" (Self 2003: $108 ; 20 ; 184)$. In this, he is Mookerjee's transgressive hero as trickster, distinguished by a transgression of boundaries, sexual transgression, and transformation, who quite literally tricks people into believing a lie and, like a predator, thrills at the possibility of perversion and ruin.

Dorian is the force of corruption whose instruments are charm and sexual omnivorousness (Self 2003: 98). His sexuality is "not ... liberated" though but "carried ... to its limits", offering itself "in the superficial discourse of a solid and natural animality" (Foucault 1977: 30-31) suggested, as we shall see, by the novel's dominant animal imagery. Dorian 
is sin incarnate on a mission to ruin people "irrespective of age, gender, race or sexual orientation" (Self 2003: 226). During the 1980s and early 1990s AIDS epidemic, initially called gay-related immune deficiency and gay plague, he is "the true retrovirus" (Self 2003: 108) that brings ruin and death. Self's antihero can therefore be understood as a metaphor for the threat that loomed large over the decades and stigmatized the gay community. While it may be true that the novel runs the risk of aligning gay subculture with both depravity and vapidity, a charge brought against it by more than one critic (see Alderson and Canning), George Matthews argues convincingly that the novel also seeks to unlock the hidden traumas from the past as it retraces the history of homosexuality, with its apparent decriminalization on the one hand, and its medical pathologization on the other (Matthews 2016: 108).

In addition, Dorian: An Imitation raises Self's concerns above the AIDS epidemic to consider it in the context of decadence on a much wider scale. On his mission to infect the society, Dorian also personifies eroticized abjection. Kristeva considers abjection a precondition of narcissism, so to reflect a narcissistic age preoccupied with media-induced images of beauty, Self appropriately replaces the painting in Wilde's original by a video installation titled Cathode Narcissus. Like abjection itself, Dorian is "immoral, sinister, scheming, and shady: a terror that dissembles, a hatred that smiles, a passion that uses the body for barter instead of inflaming it, a debtor who sells you up, a friend who stabs you" (Kristeva 1982: 4). Even in self-abuse Dorian courts abjection for "[i]n transgressive satire abjection is the relinquishment of the self" (Mookerjee 2013: 196). No other words describe Dorian better than the following definition of the threatening abject as a form of otherness.

The abject is perverse because it neither gives up nor assumes a prohibition, a rule, or a law; but turns them aside, misleads, corrupts; uses them, takes advantage of them, the better to deny them. It kills in the name of life ...; it lives at the behest of death ...; it curbs the other's suffering for its own profit ...; it establishes narcissistic power while pretending to reveal the abyss .... Corruption is its most common, most obvious appearance. That is the socialized appearance of the abject. (Kristeva 1982: 15-16) 
Self admittedly plays with the idea of the most obvious appearance of the abject through the motif of duality taken from Wilde. Duality is essential to transgression, and Dorian's duality is literalized by the artistic installation Cathode Narcissus, exemplifying the society's narcissistic obsession with image, body, and youth. In transgressive fiction, the double "serves as a way for the hero or heroine to observe and reify herself" - Dorian literally observes himself in the video and mirrors - and must often be attacked or killed "so that the hero can reclaim himself" (Mookerjee 2013: 143). Like a number of transgressive characters who epitomize psychic disorder, Dorian possesses a public and private self, the first charming and innocent-looking, yet increasingly grotesque and uncanny because he does not change, the other hidden from view in an artistic studio, suffering the consequences of Dorian's reckless debauchery, and grotesque in its decay. Dorian's double Narcissus highlights Will Self's portrayal of characters as emotional zombies surfing "a tidal wave of debauchery" (Self 2003: 55) and representing extreme alienation despite their endless socializing. They are led by the motto that life must be lived "foreshadowed by death ... and degradation", and Wotton defines them as epitomes of their time when he asserts "Too decadent? Who gives a shit about being too decadent, when to be contemporary is to be absolutely so?" (Self 2003: 47; 59).

Complementing death and violence throughout the novel is a play with grotesquerie, for the grotesque as bizarre, perverse, or incongruous (Edwards and Graulund 2013: 1-2) dominates character description. When marked by apparent disproportion or hybridity, the grotesque body is easily perceivable. However, Dorian possesses a body which is grotesque in being unnatural, ambiguous, and uncanny. Incongruence lies here in an underlying duality sensed by Dorian's lover Helen, whose comment on Dorian's surprisingly youthful appearance at a mature age marks his body as grotesque: "At first ... I found your silky hair and smooth skin a turn-on, but, to be frank, Dorian, they give me the creeps now ... I also find your baby body revolting in itself ... it isn't natural" (Self 2003: 24647). Grotesquerie bordering on monstrosity is further evoked through overwhelming animal imagery alluding to reptiles, predators, and prey, which effectively erases the border between man and animal and brings us back to abjection. "The abject confronts us ... with those fragile states where man strays on the territories of animal", and in early societies "animals and animalism ... were imagined as representatives of sex and murder" (Kristeva 1982: 12, italics in original; 13). Animalism is suggested not only 
by explicit comparisons with animals (Wotton is likened to a chameleon and a lizard who approaches Dorian's would-be lover like a predator advancing towards his quarry) or by characterization through naming (a character's nickname is the Ferret) but by an elaborate play with language. That is why the camera focusing on Dorian in the installation gives the impression of "the most intense, carnivorous, predatory voyeurism", while a gay orgy is vividly described as "a conga line of buggery" (Self 2003: 12; 68). Dorian is the novel's most dangerous predatory omnivore, so places are his "hunting grounds" and people are perceived as "game" or "specimens" whenever he is "on the lookout for the lone quarry, who could be separated out from the herd and brought to the dusty ground in a welter of stale intoxications" (Self 2003: 227).

Unlike the figures in Hieronymus Bosch's legendary painting, who at least get to relish the earthly pleasures, however false or ephemeral, on their way to Hell, the menagerie of this "garden of unearthly delights" (Self 2003: 94) never manages to truly satisfy their animal appetites. As in Money and other prototypically transgressive fictions, sexuality is stripped of all emotion since love is seen as "every man's psychosis" (Self 2003: 59). There is no love-making, but only unsatisfactory intercourse, with sexual encounters repeatedly reduced to "fucking", "screwing", and "sodomizing". Although frequently violent and orgiastic, gay intercourse is at times lyrically described, as when Baz reminisces about Dorian "screaming with delight, trussed in a sheet, his erect cock arched like a bow, a pearl of his semen on Baz's tongue" (Self 2003: 23), but heterosexual coitus never fails to disappoint. Of the Wottons, the novel asserts that "she seemed too vague and he too disengaged for them to bring their genitals into sufficient proximity with each other at the right time" (Self 2003: 41). Emphasized by technical and medical vocabulary, such emotional zombiism takes its toll on relationships, beauty, and innocence. Dorian's world is one in which beauty decays, the three Graces are substituted by she-males, and all innocence is lost. Arguably the strongest Blakean implication that captures this world in a single sentence is found in the scene where the Wottons' little Phoebe says good night to their guests: "Round and round, kiss after kiss, the imprint of lewd lips, lascivious lips, leftover lips, pink-lipsticked lips, all on her white brow." (Self 2003: 147). 


\section{The city as a "dystopic labyrinth"}

Loss of innocence and absolute decadence are trademarks of contemporary urban settings in transgressive fiction. Dystopian cities, by no means inevitably counterparts of soothing nature, have for long been common in literature, especially since the Industrial Revolution, and are found in works by authors as disparate as William Blake, Charles Baudelaire, Miguel Piñero, Don DeLillo, or Angela Carter. Latham and Hicks trace the urban dystopia from its emergence in the second half of the nineteenth century, which "coincided with - and responded to - an outburst of utopian writing ... centering on the city as a site of human perfectibility" (Latham and Hicks 2014: 163). In the aftermath of the First World War and even more so of the Second, dystopian cities became the dominant symbols of "negative possibility, as spaces of oppression, blight, and ruin" (Latham and Hicks 2014: 163) and have since suppressed all association between the city and perfectibility into oblivion. As the dark, putrescent city was a familiar image in literature prior to the eighteenth century, however, "neither the Romantics nor the modernists after them needed to invent the spectacle of the city as a dystopic labyrinth" (Gillespie 1996: 109). The same is even truer of postmodernists and post-postmodernists, whose cities drive our perceptions of urban wilderness to the extreme. DeLillo's Cosmopolis (2003) and Carter's The Passion of New Eve (1977), for instance, showcase urban chaos distinguished by street riots, crime, homeless people, urban freaks, blood, and drugs, offering direct insight into the state of society. Within this framework, transgressive fiction uses the city as locus terribilis, home of postlapsarian man and reflection of his fallen nature. In this incarnation, the city which "from its origins and such episodes as the Tower of Babel, acquired a shadow", contradicts its projection as "a meaningful human order" (Gillespie 1996: 107).

Given Self's interest in psychogeography, it is hardly surprising that the urban landscape in Dorian: An Imitation reflects the degradation of his antiheroes. In fact, the prevailing disorder and decadence are indicated by both exteriors and interiors. Streets, houses, yards, and cars are all marked by squalor and decay, mirroring the protagonists' and society's moral and physical degradation. In view of the specific subcultural context, the squalor may also be a reminder of the staple meeting place for casual sexual encounters, the public lavatory as "a key symbolic feature of urban infrastructure in gay male literature" (Woods 2014: 237). More importantly 
perhaps, the squalor contributes to an all-pervasive degradation sensed in images like those of the cut flowers in Wotton's hospital room "silently screaming as they smellily expired" and reflecting the inmates' condition, or of the filthy clutter inside Wotton's house and car that summons the idea of a "jaded century ... utterly exhausted" (Self 2003: 79; 21). Dorian: An Imitation displays a tendency to complicate the parallel between city and society by an added comparison with the body and sexuality in an Amisesque manner. Contrary to a legion of nineteenth-century "[p] opularizers of the theme of a connection between female sexuality and the physical decay and moral sickness of the city" (Gillespie 1996: 110), Dorian: An Imitation connects the physically and morally devastated city and male body and sexuality. The highly sexualized, yet drugged and infected, male body is particularly well reflected by green spaces as sites of degradation. No longer representing the city's "internalized tamed wilderness" (Gillespie 1996: 120), Hyde Park, where Sir Joseph Paxton's Crystal Palace once stood as a landmark of urban utopia and proud architectural reminder of Britain's leading role in technological advancement, is now turned into "a green gangrenous fistula in London's grey corpse" (Self 2003: 26). The image of London as a grey (Gray?) corpse aligns it with Cathode Narcissus, as it performs the same function as Hallward's artwork, hideously transformed under the burden of its morally corrupt inhabitants. Similarly, Battersea Park is "an old shambles", and "[n]o amount of imperial landscaping can cover up this malodorousness" as "the swamp lies beneath the pleasure gardens" (Self 2003: 62). This is exactly what the exceptionally beautiful and increasingly uncanny body of Dorian is, a pleasure garden on top of a malodorous swamp, a body whose celebration of "the pleasures of the sexual carnival" reveals "the skull beneath the skin" (Woods 2014: 239).

Self's novel further strengthens the link between the threatening, bruised city and body through the images of Soho as "the stinky inky heart of tentacular London" and New York "like Ancient Rome with a pituitary disorder", with "the twin towers ... like the severed legs of a brutalist robot god" (Self 2003: 178; 113). Such images evoke Ballardian spaces and are as far as possible from Le Corbusier's vision of the Radiant City, representative of Brutalism, the architectural style that Self's word choice clearly suggests. To enhance the impression, such images are juxtaposed with frequent references to interiors which are "chilly", "overstuffed", "unnecessary" and "as comfortable as a colonoscopy" (Self 2003: 54). Wotton's flat is filled with spoons, syringes, cigarette buds, joints, "overflowing ashtrays, 
empty bottles, stained wine glasses, crumpled bits of this and that", "so many empty bottles" that they form "a kind of anti-bar" (Self 2003: 4-5), while his luxury car is equally littered with opera programmes, cocaine wraps, and flasks, and covered in dust and bird droppings. The underlying impression is that Self's city is a necropolis ruled by decay and destruction simultaneously pervading the minutest details of the protagonists' microcosm and the macrocosm of world politics.

An interest in politics, vital for a piece of writing to be transgressive beyond matters of literary convention and morality, seeps into Dorian: An Imitation via occasional comments on the story's social and political background that finds its reflection in the city. The only stand the novel takes, however, is one of general critique. Britain is "a Government at once repressive and progressive, a monarchy mired in its own immemorial succession crisis, an economic recession", while resent towards America finds outlet in a denigration of the First Lady, nicknamed a transvestite, a "warmonger's wife", and the "fat Yank friend" of Princess Diana (Self 2003: $3 ; 76 ; 80)$. An even more general outlook on world politics in an atmosphere presided by disease, squalor, death, global warming, monstrosity, grotesquerie, animal imagery, and ambiguous sexuality, presents a world enmeshed in war and violence. The backdrop is painted in disconcerting images of street riots, with newspaper and television headlines serving violence as spectacle and murder as a form of popular entertainment: the civil war in Yugoslavia, Milwaukee Murders, the collapse of the Soviet Union, massacres in Rwanda, the coup in Moscow, or an earthquake in Los Angeles. The omnipresence of conflict and ensuant destruction is additionally implied by details like flowers on terraces as "a veritable riot of verdancy against an urbanity all around" above which "spore hung like a mist of blood over an ancient battlefield" (Self 2003: 6). The AIDS hospital ward is "a casualty station near the front line with Death" and a "den of disease and derangement", a service centre on the M3 has "the air of an extermination camp for drivers", trains carry nuclear waste, and a fancy restaurant offering a variety of Crustacea shells equips the eager customer with "implements required to poke, probe and scour the flesh from them" (Self 2003: 78; 107; 175; 97). The abundance of such images suggests that violence is inherent to the act of transgression; transgression is unleashed towards that which imprisons it "in its movement of pure violence" (Foucault 1977: 35). Although the novel's exquisite wording constantly reminds us of violence as a distinctive feature of the world around us, Self 
refrains from adding "a strong communal element" which would make Dorian: An Imitation "truly effective in a political sense" (Booker 1991: 93-94).

Despite, or perhaps because of its disturbing nature, the real world remains a mere background to the characters' microcosm: the world's soundtrack is muted and the radio news provides "information concerning a parallel world" (Self 2003: 8). The isolationism of Dorian's upper-class microcosm highlights the selfishness of the Thatcherite entrepreneurial agenda and showcases the same social inequalities that marked the fin de siècle dystopian cities (Latham and Hicks 2014: 163-64) and continued to widen the gap between the less privileged and the decadent elite in the 1980s. Yet, Dorian's isolated lacuna is not spared the prevailing squalor, disorder, illness, decay, and death, but is thoroughly immersed in them. As in H. G. Wells's or Ignatius Donnelly's cities, Self's postmodern urban space is where "[w]ondrous luxury coexists with brutalizing squalor" (Latham and Hicks 2014: 164). Dilapidated exteriors and interiors host bodies rapidly deteriorating due to drugs and AIDS, whose victims are compared, through another indirect political statement, to starving Africans and concentration camp inmates (Self 2003: 78). Death that lurks in the city is heralded by AIDS-affected members of the gay community who share a needle and then enjoy an orgy as "five apocalyptic jockeys" (Self 2003: 66) to the music of Joy Division's "Love Will Tear Us Apart".

Bentley finds in Self's divided and decomposing city a type of postmodernist city that is "a palimpsest of histories and narratives evoked in the psyche of the observer" (Bentley 2014: 176). He also reminds us that "the metropolis as unpredictable and potentially dangerous, where crime is rife and the darker human desires find release" (Bentley 2014: 176) is a modernist trope. Self makes ample use of this trope in depicting a world of unleashed dark desires, and it is precisely their release that makes the city unpredictable and dangerous. The sense of unpredictability and danger is highlighted by the transgressive characters' indispensable closeness with death that is consciously maintained through the destructive and selfdestructive acts of Self's "rotten bunch" (Self 2003: 104). In their world of dangerous urban decadence, even working out fails to contribute to the population's health and is, instead, yet another plague from the US designed to counterbalance HIV (Self 2003: 129). Unpredictability and danger are further developed through Self's replacement of "the acceptable homosocial conventions of society clubs and residences" and Dorian's 1890s' excursions 
to the docklands "to experience the riskier, racier pleasures" (Woods 2014: 235 ) in Wilde's original with an omnipresence of such pleasures in the 1980s and 90s. Homoeroticism, widely perceived as a threat during the AIDS epidemic, ventures forth from clubs, private residences, brothels, and opium dens to pervade every social space. Dorian's originally secret life becomes his public life and his erotic interest in "the physical heft of proletarian masculinity" (Woods 2014: 235) transforms into flamboyant sexual omnivorousness wedded to the grotesque and the animalistic.

The city is thus configured in Dorian as the site of abjection itself, the entry point to Kristeva's "territories of animal", where the antihero's degradation and self-destructiveness find their spatial expression. At the same time, the extreme nature of the imagery used to describe Self's urban landscape mired in decadence and depravity can be seen as satirical commentary on the social order which casts his antiheroes both as its apotheosis and as its diseased and depraved Other. The medicalized images of the city's decay ("gangrenous fistula") hint at the flip side of the entrepreneurial glitter of the greed-driven decade - the acute reality of human suffering under the weight of the AIDS epidemic. This is further underscored by the novel's epilogue, which reveals that the narrative is in fact written by the ailing Wotton. The hedonistic excess of the central narrative is thus relativized as a fictitious account written by a dying man, and the focus is shifted away from the wild(e) decadence of the gay community, which led to accusations of "cheap flippancy" and "hostile prurience" (Canning 2014), towards the wider social context in which the novel operates - both the Thatcherite entrepreneurial eighties and the New Labour policies of the nineties. Dorian, the true retrovirus of Wotton's manuscript, sowing death and misery wherever he treads, is reintroduced as a successful media mogul, a lithe embodiment of the image-obsessed spirit of the age, the flag on his imposing headquarters fluttering "like a banner" (Self 2003: 265) over the city, claiming it for its fashionable CEO. The epilogue also offers a sanitized, aestheticized version of the homosexual which can be coopted by mainstream consumerist culture owing to a shared "embrace of style over content" (Matthews 2016: 112), but which can also serve as a convenient, already reviled symbol of "social privilege and ostentation" (Alderson 2006: 320), a useful target for the rage of the disaffected and the disenfranchised.

The epilogue at first seems to offer another view of London, in a cavalcade of glitzy addresses couched in the "world spirit of stylishness" 
- the Grosvenor House Hotel, Primrose Hill, the smart clubs of West End, the Royal Academy - mirrored by the "immaculate interior" of Dorian's car and the neat geometrical layout of his business premises, "the go-faster chevrons of the mullions, the balconies like the pulled-out drawers of a filing cabinet" (Self 2003: 266; 262; 265). However, as Wotton's voice starts to invade the framing narrative, the cityscape changes again, first with a "silent throng ... converging on Kensington Palace", as the crowds gather to mourn the death of Princess Diana, then a whiff of "the sickly perfume of a thousand bunches of cut flowers", eventually followed by a turn into "Rotten Row", sliding into "a pile of horse droppings" (Self 2003: 276-77). As Wotton metamorphoses into Ginger and leads Dorian to his death, the two narratives and the two cityscapes converge in a place of abjection, the public toilet, in "the piss-filled runnel of the urinal" (Self 2003: 278). Dorian's anodyne version of the homosexual is thus confronted with the site of the public toilet, loaded with subcultural significance, where it is literally destroyed, "hardly likely to remain fashionable for very long at all" (Self 2003: 278). Furthermore, Alderson suggests that the murderer may be read as a random skinhead who takes the form of Ginger in the increasingly ambiguous final pages of the narrative, in which case the site of dubious sexual freedom is reinterpreted as a site of homophobic violence, persistent even in the age of wider social acceptance of alternative sexualities (Alderson 2006: 325).

\section{Dorian: An imitation and the new satiric tradition}

The novel's ambiguous ending contributes to Self's quoted intention to stimulate the readers to think for themselves in a time of moral relativism. His overall satiric critique is designed to do the same, and its principal instruments are the novel's most obviously transgressive features, the antihero and the city. In-depth analysis has shown that these features are the novel's primary source of subversive potential, which is aimed at the dominant ideologies and institutions of the entrepreneurial 80s and the 90s, confirming Booker's idea that a truly transgressive work needs to address the real world of history and politics. Dorian: An Imitation debunks the era's myths of money and mocks its preference for traditional family values by focusing on a small group of decadent and narcissistic individuals whose social and cultural privilege grants them no success. The 
morally neutral description of their empty socialising, substance abuse, and emotion-free sexuality indeed reveals a world that, according to Foucault, no longer recognizes the positive in the sacred.

To deliver this point effectively, Self portrays Dorian as a fitting antihero, Mookerjee's transgressive trickster, "sleek monster", and perfect embodiment of "the transgressive artist's penchant for revealing what is true but not ordinarily visible" (Mookerjee 2013: 7; 10). In Bataille's terms, for Dorian every prohibition is there to be transgressed, so his sexual omnivorousness makes him an apt metaphor for the greed and narcissism of the decade that he epitomizes. The novel's physically beautiful but morally decrepit model for Cathode Narcissus is also representative of Kristeva's threatening abject that denies prohibitions, rules, and laws, and his rebellion against the tenets of conventional society is presented as a corrosive force. Within the context of the AIDS epidemic that discredited the gay community, Dorian is the virus at work in society at large, and the havoc he wreaks is mirrored by the pervasive disorder of the expectedly dystopic urban setting.

Like Self's antihero, the city is a site where luxury and squalor meet in exteriors and interiors characterized by filth, clutter, and dilapidation as a reflection of the society's fallen state. The city as Gillespie's dystopic labyrinth is where the antihero's sexuality and desire for closeness with death find their outlets in expressions of violent animality. The pervasive animal imagery helps to transform the city as a projection of order into an urban wilderness where the affluent and the underprivileged of all ages, genders, races, and sexual orientations are bound together by a sense of danger that lurks in the form of the retrovirus, AIDS and Dorian.

Self's portrayal of a violent, grotesque, and emotionally depraved world of narcissistic and (self-)destructive antiheroes aligns Dorian: An Imitation with what Mookerjee sees as the new satiric tradition. While it is too far-fetched, and untrue, to claim that the transgressive fiction which Self's novel represents is "hostile ... to the western civilization" (Hume 2012: xi) as a whole, the novel certainly provides a critique of its decadence. Dorian: An Imitation paints a picture of an aggressive reality whose incoherence endows the novel with subversive energies, unlocking its transgressive potential (Booker 1991: 212). The novel fulfils this potential in the form of biting satire whose chief instruments are the antihero and his setting that expose the corrosive forces at work in society: widespread economic disparity, political manipulation, moral 
degradation of both individual and society, and violence as its common outlet. Establishing a dialogue with the turn of the $20^{\text {th }}$ century, Self takes a historical look of the social, economic, and moral evils of the end of the $20^{\text {th }}$ century. Dorian's set exemplifies the decadence that follows excess at the expense of the underprivileged, cultural stagnation, moral vapidity, and emotional sterility, all reflected by physical decay, and Self's "imitation" of Wilde's narrative indicates that such excess and decadence change context but persist. Following on Wilde, Self offers a close-up of dehumanization that results from "a character intent on gorging on metropolitan excess" (Bentley 2014: 176-77), taking his cue from the age-old idea of the sexual perversity of city life. Admittedly, Self's novel is no example of political satire of the kind we encounter in George Orwell's Nineteen Eighty-Four (1949), which "forecasts the political devolution of the city into a tyranny of centralized administration and control" (Latham and Hicks 2014: 166), nor is it a dystopian projection of the future. Instead, the images of Self's sin city take a more general satirical outlook on progress, technological growth, and advancement towards a more civilized existence.

As Booker reminds us, "[s] ubversion requires a target: transgression of boundaries requires that those boundaries initially be in place" (Booker 1991: 87-88). Employing transgression, identified by Booker as a technique of subversion, Self's novel satirizes a civilization at the point of exhaustion that dismisses the ideas of progress, growth, and advancement. To formally enact this, the novel runs the risk of exhausting itself in an incessant play of boundaries and transgression. Even transgression itself may be exhausting its nature by a constant crossing and re-crossing of boundaries: "Does transgression not exhaust its nature when it crosses the limit, knowing no other life beyond this point in time?" (Foucault 1977: 34). Instead of answering this question, Self allows it to hover over his narrative in which everything is exhausted: culture, economy, climate, politics, morality, body, and emotion. It is no wonder then that Hume feels reading such transgressive fiction is evidence of "reader masochism" (Hume 2012: xiii). Yet, this fiction is perfectly fit for an age which witnesses transgressions of borders of such magnitude that they become blurred. Subversion through transgression in fiction that has all but forgotten traditional patterns of plot, character, and structure which gratify reader expectations has become so prevalent that more traditional and realistic narratives such as Min Jin Lee's Pachinko (2017) read like refreshing anachronisms. If literary transgression depends on the transgressive energies of the reader, 
on their identification and acceptance of the work's transgressive potential (Booker 1991: 15), then fiction like Dorian: An Imitation requires readers who do not derive pleasure from "moral rightness" (Hume 2012: 5). In its questioning, through character and setting, of the moral rightness of the times, Dorian: An Imitation represents one of those revolutionary moments in the history of literature which exemplify that transgression of boundaries is "an essential feature of literariness" (Booker 1991: 3).

Contributing to a long satiric tradition that relies on that essential feature, Self seems to ridicule the uphill task of attempting to "achieve any kind of authentic transgression in our modern cultural climate" (Booker 1991: 10). His self-ironic "imitation" undermines authenticity in a time when it is increasingly difficult to avoid the appropriation of subversive energies by the very dominants that one is intent on satirizing. Perhaps it is because the subversive energies of transgression have been exhausted by the fact that some form of transgressivity is expected in literature and art that the movement headed by Burroughs has led "toward more and more shocking and graphic depictions of transgressive violence in modern literature" (Booker 1991: 146). This tendency seems to have reached its peak in the last decade of the $20^{\text {th }}$ and the first decades of the $21^{\text {st }}$ century. Self refrains from such depictions but, like the more graphic Fight Club or American Psycho, puts violence to satiric purpose. Negative criticism which shows that transgressive satire causes a disturbance, much like it did when Swift published A Modest Proposal (1729), treats transgressive fiction as shock lit. Irvine Welsh, himself an exponent of transgressive literature, claims that anyone can write shock lit, so the point is to make the book bigger, to make it about the world we live in (Welsh 2016). In that sense, he sees American Psycho not as a novel about an individual's psychotic behaviour, but a book about the economic system which compels such behaviour. While such fiction disturbs by its satiric outlook on society which confirms that "[t]here exists no prohibition that cannot be transgressed" (Bataille 1986: 63), it also serves as an eye-opener that destabilizes common perceptions of the world. In our self-righteous moment in history when phenomena like cancel culture pose a threat to critical thought and open debate by insisting on intellectual conformity, Dorian: An Imitation and transgressive fiction at large reinstate the importance of critique that opposes dogmas and nourishes dialogue. 


\section{References}

Alderson, D. (2006). 'Not everyone knows fuck all about Foucault': Will Self's Dorian and Post-Gay Culture. Textual Practice, 19.3, 309-29. (10 March 2021) <doi.org/10.1080/09502360500196284>.

Bataille, G. (1986). Erotism: Death and Sensuality. Translated by M. Dalwood. San Francisco: City Light Books.

Bentley, N. (2014). Postmodern Cities. In: K. R. McNamara (ed.), The Cambridge Companion to the City in Literature, New York: Cambridge University Press, 175-87.

Booker, M. K. (1991). Techniques of Subversion in Modern Literature: Transgression, Abjection, and the Carnivalesque. Gainesville: University Press of Florida.

Bowers, M. A. (2004). Magic(al) Realism. London and New York: Routledge. Bradbury, M. (1993). The Modern British Novel. London: Secker \& Warburg. Canning, R. (2014). Dorian: An Imitation, by Will Self. Outdoing Wilde in Sex, Excess and Snobbery. The Independent. (10 March 2021) < http:// www.independent.co.uk/arts-entertainment/books/reviews/dorianan-imitation-by-will-self-139656.html> .

Edwards, J. and R. Graulund (2013). The Grotesque. New York: Routledge. Foucault, M. (1977). A Preface to Transgression. Translated by D. F. Bouchard and S. Simon. In: D. F. Bouchard (ed.), Language, CounterMemory, Practice: Selected Essays and Interviews, Ithaca: Cornell University Press, 29-52.

Gillespie, G. (1996). The City of Wo/Man: Labyrinth, Wilderness, Garden. Comparative Criticism, 18, 107-25.

Hayes, M. H. (2007). Understanding Will Self. Columbia: University of South Carolina Press.

Hume, K. (2012). Aggressive Fictions: Reading the Contemporary American Novel. Ithaca and London: Cornell University Press.

Kristeva, J. (1982). Powers of Horror: An Essay on Abjection. Translated by L. S. Roudiez. New York: Columbia University Press.

Latham, R. and J. Hicks (2014). Urban Dystopias. In: K. R. McNamara (ed.), The Cambridge Companion to the City in Literature, New York: Cambridge University Press, 163-74.

Matthews, G. (2016). Will Self and Contemporary British Society. Basingstoke: Palgrave Macmillan. 
Mookerjee, R. (2013). Transgressive Fiction: The New Satiric Tradition. Basingstoke: Palgrave Macmillan.

Self, W. (2003). Dorian: An Imitation. London: Penguin.

Silverblatt, M. (1993). Shock Appeal / Who Are These Writers, and Why Do They Want to Hurt Us?: The New Fiction of Transgression. Los Angeles Times. (12 January 2021) < http://www.latimes.com/archives/la-xpm1993-08-01-bk-21466-story.html>.

Taylor, L. (2007). The Luxury of Doubt: Laurie Taylor Interviews Will Self. New Humanist. (12 January 2021) <http://newhumanist.org.uk/ articles/655/the-luxury-of-doubt-laurie-taylor-interviews-will-self $>$.

Welsh, I. (2016). The State of Transgressive Fiction. Unprintable: The LitReactor Podcast Episode 26. (12 January 2021) < http://litreactor. $\mathrm{com} /$ podcast/unprintable-the-litreactor-podcast-episode-26-the-stateof-transgressive-fiction-guest-irvine-welsh $>$.

Woods, G. (2014). Gay and Lesbian Urbanity. In: K. R. McNamara (ed.), The Cambridge Companion to the City in Literature, New York: Cambridge University Press, 233-44.

Received: 24 June 2021

Accepted for publication: 20 July 2021 